\title{
Beberapa Temuan Prasasti Baru Di Indonesia
}

\author{
Sukarto Karto Atmodjo
}

Keywords: inscription, epigraphy, Ancient Indonesia, Hindu-Buddha, archaeology

\section{How to Cite:}

Atmodjo, S. K. Beberapa Temuan Prasasti Baru Di Indonesia. Berkala Arkeologi, 14(2), 1-5. https:// doi.org/10.30883/jba.v14i2.630

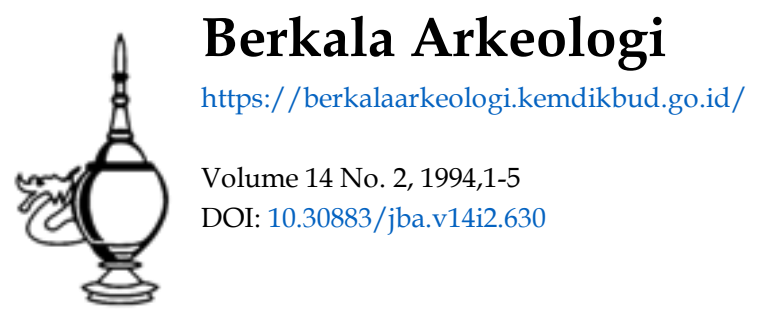

\section{cc) (i) (2)}

This work is licensed under a Creative Commons Attribution-NonCommercial-ShareAlike 4.0 International License. 


\title{
BEBERAPA TEMUAN PRASASTI BARU DI INDONESIA
}

\author{
M.M.Sukarto K. Atmodjo \\ (Balai Arkeologi Yogyakana)
}

\author{
Er luidt en klokje van scheiden \\ Hier rustloos door het dal \\ ' $k$ weet dat het voor ons beiden \\ Ook-eenmaal klinken zal \\ Maar zijn we ook van elkander \\ Wat ook het lot ook biedt \\ Vertrouw op mijn lieve zuster \\ Vergeten zal ik u niet.
}

\section{Surat R.M. Sosro Moeljono kepada kakaknya R.A. Kartini \\ (kutipan dari majalah Selera, bulan April, 1982, h/m. 19)}

Dalam rangka purna-bhakti saya sebagai petugas epigrafi dari Balai Arkeologi Yogyakarte, saya akan meninjau secara sekilas beberapa temuan prasasti baru di Kalimantan, Sumbawa, Sumatra dan Jawa Namun demikian perlu saya jelaskan bahwa dua buah temuan di antaranya, yartu di Kalimantan, sudah lama ditemukan dan diteliti oleh para ahli, tetapi sampai sekarang pun belum juga tuntas. Temuan itu sebetulnya cukup banyak, tetapi pada kesempatan dan waktu yang baik ini (subha diwasa), saya hanya akan mengulas sebagian temuan tersebut secara singkat. Semula saya akan menguraikan segala sukaduka sebagai petugas epigrafi dan juga sejarah penelitian epigrafi Indonesia. Tetapi masalah suka-duka terlalu bersifat pribadi dan kurang mengena (relevant), sedangkan sejarah penelitian epıgragi telah diuraikan secara baik oleh almarhum Drs. A.S. Wibowo dengan judul riwayat Penyelidikan Prasasti di Indonesian (50 Tahun Lembaga Purbakala dan Peninggalan Nasional 1913-1963). Memang pada waktu itu A.S. Wibowo baru menyebut para penyelidik seperti T.S. Raffles, C.J. Van der Vlis, R.H. Th. Friederich, H.Kern, K.F. Holle, A.B. Cohen Stuart, J.L.A. Brandes, N.J. Krom, F.D.K. Bosch, W.F. Stutterheim, R.M. Ng. Poerbatjaraka, P.V. van. Stein Calenfels, R. Goris, L.ch. de Casparis, L.Ch. Damais, B.Ch. Chhabra, J.Ph. Vogel. K.A. Nilakanta Sastri, R. C. Majumdar, H.Bh. Sarkar,

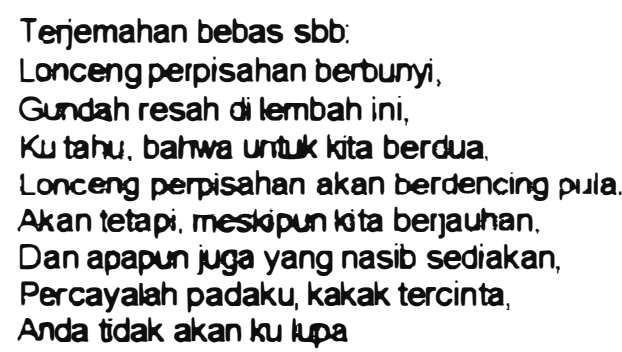

G. Coedes dan G. Ferrand. Deretan para sarjana epigrafi itu dapat ditambah lagi seperti K.C Crucq, F.H. van Naerssen, Th. Pigaud, Boecharı, Ktut Ginarsa, Moh umar, Issatriadi, van Wis. seman Christie, A.M. Barrett Jones, W.J vander Meulen S.J., Kōzō Nakada, dll Selain itu juga masih banyak para peneliti prasasti yang tekun dan pandai yang sekarang bekerja di Fakultas sastra U.G.M., U.I., Unud dan di kantor Purbakala. Bahkan dari masyarkat pun ada beberapa yang tertarik masalah epigrafi Sejarah Indonesia Kuno), a.I. Sdr. Radix Penadi. Ternyata limu Prasasti (Arkeologi, Sejarah Kebudayaan) bukannya monopoli para sarjana yang mendapat pendidikan masalah tersebut, tetapi umum pun berhak menjadi penyelidik (pengamat) prasasti, sejarah, dan kebudayaan

Beberapa prasasti yang menarik, yang merangsang perhatian saya dalam dasa warsa terakhir ini sebetulnya cukup banyak, tetapi pada kesempatan inı, saya hanya akan membahas sebagian di antaranya, ialah

\section{Prasasti Batu Pahat}

Prasasti Batu Pahat terdapat di pedalaman Kalimantan Barat, yaitu terletak di kampung (desa) Pahit (Kecamatan Nanga Mahap, Kabupaten Sanggau. Propinsi Kalimantan Barat). Desa Pahit terletak sekitar $\mathbf{4 0 0}$ kilometer dari Pontianak melalui jalan darat dan jalan sungai. Prasasti itu sebetulnya sudah diketui oleh orang barat (melalui foto dan faksimil), tetapi permasalahannya belum juga tuntas. Secara jujur, memang harus dikatakan, bahwa sampai sekarang pun permasalahan prasasti Batu Pahat belum terpecahkan semuanya. Prasasti ditatah pada bidang batu besar yang diratakan, berukuran panjang batu 5.70 meter, tinggi 3.46 meter. Di samping belakang prasasti, sekarang terdapat kuburan Katolik karena penduduk Kampung Pahit mayoritas 
beragama Katolik dan beberapa orang di antaranya menganut kepercayaan Kaharingan (jumlah penduduk sekitar 300 orang). Penelitian pernah dilakukan oleh sebuah tim Puslit Arkenas pada tahun 1983 dan 1985

Menarik perhatian bahwa di bagian bidang rata batu tersebut terdapat 7 buah pahatan stūpa dengan chattra (payung) susun 13 di atasnya. Karena penduduk setempat tidak mengetahui, maka chattra yang teratas dianggap sebagai lambang salib (lihat gambar dari Puslit Arkenas). Tinggı stūpa bermacam-macam (bervariasi), antara 1.55 meter dan 2.45 meter. Sebuah pahatan tidak jelas apakah menggambarkan senjata gada atau sendok, tetapi menurut perkiraan saya, mungkin melambangkan pattra (cf. suwarna pattra). ${ }^{2}$ Pada bagian bawah stūpa dan chattra (?), seluruhnya terpahat deretan beberapa baris aksara Pallawa yang sangat aus. Mengenai paleografinya, Prof. Chhabra mengatakan: 'somewhat later than the famous yupa inscription of King Mulawarman': Supaya jelas, stūpa tersebut saya namakan dari kiri (yang terendah) ke arah kanan dengan stüpa I, II, I, IV, V, VI, dan VII. Pembacaan ternyata sangat sulit dan melelahkan. Tetapi akhirnya setelah lama mengamatamati dari samping kiri, kanan, dan depan mencari efek sinar matahari, dan juga menggunakan teropong (binoculars), sebagian tulisan dapat ditebak. Terbukti stūpa I antara lain menyebut wādi mahāsramanah. stupa $N$ wādi mahāsramanah (baris 10 dan 11), stūpa $V$, dan mahāsramanah stupa VI mahãsramanah (baris 9 dan 10). Demikianlah maka teka-teki yang menyelubunginya dapat ditebak, artinya Prasasti Batu Pahat di pinggir Kali Tekarek tersebut memuat ye-te mantra yang sangat terkenal dan juga japa-mantra agama Budha lainnya. Ye-te mantra lengkapnya berbunyi sebagai berikut

ye dharmma hetu prabhawā

hetun-teșān tathågato hyawadat

teșān-ca yo nirodhā

ewamādi mahāsramaṇah.

Keadaan tentang søbab musabab itu telah diterangkan oleh Sang Budha (Tathägata), tuan mahatapa itu telah menerangkan juga apa yang harus diperbuat orang supaya menghilangkan sebab musabab.

Sayang sekali japa-mantra lainnya belum (tıdak) dapat diketahui. Tetapi stūpa $\vee$ (baris 12) dan stūpa VII (barıs 9) menyebut perkataan jeya dan wijaya. Wolters mengatakan, bedasarkan

\section{Suwarna-patta yang digutung di dalam pipih dan} digores dengan japa-.antra (wijaksara) ada juga yang berbentuk menyerupai sendok atau senjata (panjang lancip; berita cina, bahwa di Borneo barat daya dalam abad VII pemah berkembang kerajaan Wilayapura. Terakhir perlu ditambahkan bahwa pahatan yang menggambarkan pattra (?) tersebut juga digores dengan tulisan pendek (setiap baris 3 atau 4 huruf) sejumlah 22 baris. Pengamatan sementara menunjukkan bahwa pada baris pertama (1) dan kedua (2) cukup jelas terbaca perkataan poșa māsa çake 578 (bulan Posa tahun Çaka 578)

\section{Prasasti Batu Sampai.}

Prasasti Batu Sampai terpahat pada sebuah batu berukuran $7 \mathrm{~m}$ dan tinggi $1.02 \mathrm{~m}$, terletak di pinggir Sungai Sekayam, anak Sungai Kapuas, Sanggau. Tulisan hanya sebaris dan panjang tulisan sekitar 2 meter. Jumlah aksara 8 atau 9 buah. Menarik sekali bahwa bentuk aksara menyerupai gambar ikan (huruf ikan), mungkin ikan ulang uli dalam mitologi. Faksimil tulisan pernah disampaikan kepada Prof.H. Kern, tetapi belum juga berhasil dibaca ${ }^{3}$ Kern sendiri mengatakan: "I am sorry to say, that my endevours to unriddle the contents have been fruit-less". Tetapi dikatakan selanjutnya bahwa kalimat pertama baris kedua berbunyi prabhuh. Pengamatan setempat menunjukkan bahwa Prasasti Batu Sampai hanya terdiri atas sebaris tulisan, mungkin berbunyi Sri bhupati tirthāyatra (lihat faksimil). Sayang sekali teka-teki batu ber-tulis di tepi Sungai Sekayam tersebut tetap belum terpecahkan. Ini merupakan satu tantangan (challenge) bagi para ahli purbakala untuk menjawabnya (response), sebeIum tulisan hapus, karena apabila Sungai Sekayam banjir, tulisan itu terendam air.

\section{Prasasti Wadu Tunti.}

Prasasti Wadu Tunti terletak di Kampung Padende (Desa Doro, Kecamatan Donggo, Kab. Bima), terpahat pada sebuah batu besar di pinggir jurang yang dalam dan dikelilingi puncakpuncak pegunungan tinggi yang mempesona. Prasasti bati itu, oleh Penduduk setempat (letaknya jauh dari desa) disebut Wadu Tunti (batu tulis). Tidak jauh dari situs prasasti, juga ditemukan peninggalan megalitik berupa palungan aır yang cukup besar. Tulisan sebanyak 10 baris dan sebagian pecah dan aus Di samping tulisan terdapat relief menggambarkan seseorang yang sedang duduk di hadap seek or harimau (cerita Bhubhuksah?). Prasasti menggunakan huruf dan bahasa Jawa Kuna (tercampur bahasa lokal). Sebagian prasasti yang terbaca berbunyi lebih kurang sebagai berikut

Lih. H. Kem: Note on Writing in Bomeo, dalam V.G (Verspreide Geschriften), Zevende Deel, 1917 him. 157-161. 
1. Il ri wruhani..

2. nira sajlumiwat

3. ta wani winidhi sahilanñ à

4. tañi bhalay geni ọuputan lani balutani

5. nilan pinini mahilay nia nira saj ñäji sapalu yiki

6. bā hanipuh-apa ri saựatén à ri sapalu //

7. pagluria piḍu ri kasa //

8. ... sira say nanatura

9. ... ruwa g nira sajnaji

10. ... sapalu //

Terjemahannya:

1. Ketahuilah ...

2. beliau (mereka) yang melewati tempat inı (liwat)

3. berani ditentukan (dipilih) akan hilang

4. ... melemparkan api, gugur (duputan) langit

5. hilang ditiadakan (pininı) hilanglah (mokṣa?) beliau Say Nāji (raja) Sapalu ini

6. menghancurkan (hanipuh) ketika beliau datang di (negara) Sapalu.

7. pergi lenyap (pajluna) ke angkasa (?),

8. ... beliau yang akan mengatur (menyampaikan)

9 ... teman (pengikut) beliau San $\dot{N}^{2} j i$

10. ... Sapalu.

Isi pokok Prasasti Wadu Tunti yaitu menyebut seorang tokoh raja bernama Sang $\bar{A} j i$ Sapalu yang bertahta di negara Sapalu. Dikatakan bahwa Sang $\bar{A}$ ji Sapalu telah hilang (mokșa, wafat), rupa-rupanya setelah terjadi peperangan (bhalang geni: lempar api). Dalam sejarah Indonesi kuna nama Sang Āji Sapalu baru pertama kali diketahui dalam prasasti Wadu Tunti (dibaca tahun 1983). Pertanyaan apakah Sang Āji Sapa-lu berkaitan dengan peristiwa padompo dalam $\mathrm{Pa}$ raraton masih memerlukan penelitian lebih lanjut. Dikatakan bahwa peristiwa Pasunda bersamaan dengan Padompo (tunggalan padompo pasuṇa). Peristiwa Pasunda terjadi pada tahun sangaturangga-pakça wani $(1279=1357 \mathrm{M})$.

Juga dicatat dalam sejarah bahwa dalam pemerintahan raja Jāyānāgara, patih Gajah-māda bersama-sama Âryya Damar menundukkan kerajaan Bedahulu dekat Gianyar. Angkatan laut mendarat di dekat Gianyar dan Kuta. Panglima Bedahulu tewas dalam peperangan dan raja pasung Rigih ditangkap. Dalam tangkapan, maka Pasung Rigih menerima nasibnya, sehingga diberi ampun oleh patih Gajahmada. Pasung Rigih lalu diangkat menjadi panglima yang menyerang pulau Sumbawa melawan raja Dedela Nata

Kasa juga berarti glagah (padang glagah. alangalang)
(Werdamürti). Dalam peperangan maka ke duaduanya gugur.

\section{Prasasti Boom Baru.}

Temuan menarik dari Palembang yaitu sebuah prasasti batu yang semula tergali di Boom Baru dan sekarang tersimpan dengan baik di Museum Balaputradewa Palembang. Dengan mendapat bantuan penuh dari Bapak Drs Syamsir Alam (Kepala Museum Balaputradewa) saya berhasil membacanya pada tahun 1992, dan memberikan ceramah: Prasasti Boom Baru dan Kaitannya dengan Kerajaan Sriwijaya di museum Balaputradewa (13 Agustus 1992). Ternyata prasasti itu berisi kutukan atau sumpah (sa-patha) kepada siapa saja yang berani melawan atau melanggar peraturan kedatuan Sriwijaya Prasasti menggunakan huruf dan bahasa Melayu kuna (O/d Malay). Ditinjau dari segi paleografi prasasti berasal dari sekitar akhir abad VII Masehi Transkripsi selengkapnya sebagai berikut 1. ... (nivja) rim droha (ka).

2. tida ya bhakti tatwa arjäwa dy-aku dnan.

3. wunuh ya sumpah ni(suruh) tāpik-ya. . sriwija).

4. ya diran gotra santanānya.

5. maka lariit. urang maka sakit maka gila

6. upuh tüwa kasihan wasikarana itye (wamadi).

7. pulanka yan muah yan dosanya muah

8. kadaci ya bhakti latwa arjäwa dy-aku

9. datua santi muah (kawuatanya) dnan gotra (santananya)

10. samrddha swastha niroga nirupdrawa subhiksa mivah ya wanunan

11. ya paräwis $10 \mathrm{OV}$

Artinya lebih kurang sebagai berikut

1. (dikatakan) durhaka

2. (apabila) ia tidak bakti dan tunduk (bertindak lemah lembut) kepadaku dengan

3. dibunuh ia oleh sumpah dan di (suruh) supaya ya hancur oleh. (Sriwija)

4. ya dengan sanak keluarganya

5. menyebabkan orang hilang ingatan (maka lanit), menyebabkan orang (maka sakit) dan menyebabkan orang gila (maka gila)

6. racun (upuh) dan tuba (tüwa), menggunagunai orang supaya jatuh cinta (kasihan), mengguna-gunai orang supaya tunduk pada kemauannya (wasikarana), dan demikian selanjutnya (ityewamadi)

7. kembali (pulag) ka asalnya lagi ke dosanya lagi

Lih. Muhammad Yamın: Gadjah Mada. Balai

Pustaka. 1972, hal. 47 
8. tetapı apabila setiap kali (kadācı) ia berbakti dan tunduk kepadaku (dy-aku)

9. dan taat kepada kedudukan raja (datua) ia akan menemukan kembali (kawuatanya: per. buatannya)

10. kesentausaan dan keselamtan (sānta), sehat walafiat (niroga), bebas mala petaka (nirupadrawa), makmur (subhiksa)

11. seluruh negara (wanuanya parāwis) /1 0 //

Dengan temuan baru tersebut, sampai sekarang telah ditemukan 6 buah prasasti batu yang memuat sapatha (kutukan). Prasasti kutukan itu (imprecation formula) semuanya terkait dengan kerajaan Sriwijaya. Nama urutnya sebagai berikut

1. Prasasti Kota Kapur (tepi S. Munduk, pulau Bangka, bertarih 608 Saka = 686 M.),

2. Prasasti Karang Brahi (Upper Jambi)

3. Prasasti Telaga Batu (di museum Jakarta),

4. Prasasti Palas Pasemah (Lampung Selatan),

5. Prasasti Bungkuk (Jabung, Lampung Selatan)

6. Prasasti Boom Baru (di museum Balaputradewa, Palembang)

Di antara 6 buah temuan tersebut, batu Boom Baru merupakan prasasti yang terpendek isinya. Tetapi pada garis besarnya bunyi (isi) sumpah kutukan tersebut semuanya hampir senada. Sayang sekali bagian atas prasasti Boom Baru telah pecah dan hilang, sehingga sekitar 4 atau 5 baris tulisan tidak dapat diketahui bunyinya. Meskipun demiian masih dapat diperkirakan bunyinya mirip dengan kalimat awal prasasti kutukan Kota Kapur, Palas Pasemah dan Bungkuk (Jabung)

\section{Prasasti Adan-adan}

Prasasti tembaga Adan-adan (tamraprasasti) ditemukan di daerah Bojonegoro (Jawa Timur) dalam tahun 1992, dan dibaca oleh tim Balar Yogyakarta dalam tahun itu juga. Sekarang disimpan di museum Tantular Surabaya. Prasasti terdiri atas 17 lempengan tembaga (lengkap), dan kecuali lempengan pertama, ditulis timbalbalik (recto dan veriso) sebanyak 4 baris setiap lempengan. Tembaga berukuran panjang 37,5 $\mathrm{cm}$, lebar $12 \mathrm{~cm}$, dan tebal $0,4 \mathrm{~cm}$. Isi pokok yaitu pemberian status swatantra (perdikan) Desa Adan-adan, karena (sambhanda) seorang rajarsı (wanita) telah berjasa, bertingkah-laku baik dan berbakti kepada negara, agama dan raja Majapahit

Dikatakan dalam prasasti Adan-adan (sekarang menjadi desa Adan-adan di daerah Kediri) alasan (sambandha) pemberian anugerah berupa daerah bebas pajak (sima swatanträ) tersebut, karena rājarși memiliki beberapa sifat terpuji, a.l. a. Walkalodhari.
Selalu mengikuti duka-nestapa raja, berpakaian kulit kayu (walkala: pakaian ku-lit kayu anyaman, dhari: pemakai, dengan suara panjang menunjukkan seorang wanita)

b. Sasilasuddhācāra.

Bertingkah-laku sesuai dengan tata susila yang baik (sila: perangai, susila, suddha: sempurna, ācāra: laku, Jalan, cara)

c. Satata dharmmacintana.

Artinya selalu taat beragama, cınta kebaikan (satata: selalu, dharma: agama, kebaikan cintana: cinta)

d. Dewārccanā.

Berbakti dan menyembah Tuhan (dewa: Tuhan, Sang Hyang Widhiwasa, Dewa atau Kekuatan Yang Maha Tinggi, arccanā: menyembah, kebaktian)

e. Mrārthānakna pagěhani pangdiri sri mahärāja ring ratna kanāka singhasana.

Memperjuangkan kokoh kuatnya kedudukan Sri Mahārāja di atas takhta singgasana yang terbuat dari ratna dan emas (kanaka)

Selanjutnya prasasti juga menyebut desadesa parimaṇdala (desa sekitamya) secara lengkap, seperti: Wadung, Tinawun, Tambangan, Kawengan, Jajar, Tambar, Padasan, dan sawah di Kèmeng, Nabak, Sancja, Tāmbak, Barat, Kubwan, dan Kubwan Agěde. Nama-nama itu sebagian besar masih dikenal di daerah sekitar desa Adan-adan (Pare) sekarang. Nama Adan-adan (tembaga Adan-adan, 1223 Saka) sama dengan Hada-hada (batu Paradah, 865 \$aka, OJO XLVIII). Sampai sekarang jumlah prasasti raja Krtarājasa Jayawardhāna (Narāryya Sanggramawijaya) dari Majapahit yang sudah ditemukan sebanyak 4 buah, yaitu

a. Tembaga Kudadu (1294 M.),

b. Tembaga Sukāmña (1296),

c. Tembaga Adan-adan (1301 M.),

d. Tembaga Balawi (1305 M.).

\section{Prasasti Wutit}

Prasasti batu tersebut terletak di pınggır sawah dekat tebing Kali Kitiran, di Dukuh Tumbrek (Desa Tumbrek, Kec. Bandar, Kab Batang). Situs temuan disebut Kandangan oleh

${ }^{6}$ Lih.R.Ng.Dr.Poerbatjaraka (met inleidende opmeriongen door Dr.W.F Stutterheim): Oorkonde van Krtorajasa uit 1296 A.D. (Penangoengan), INI (Inscripties van Nedertandsch-/ndie), aflevering 1. $\mathrm{nkm} .33-49$

${ }^{7}$ Prasasti Adan-adan sedang saya garap. Menunt penduduk Adan-adan sekarang (Pare, Kediri, berdekatan dengan Gurah) nama itu berasal dari adzan. Yang betud dari bahasa Jawa asll ada-ada (persiapan, cikarbakal, inisiatif). Nama yang lebih tua yaitu Hadahada (prasast Paradah, 943 M.) 
penduduk setempat, karena di tempat itu terdapat sebuah arca Nandi (rusak) dikelilingi 4 buah tıang batu (stone pillars) berbentuk persegi panjang. Bagian atas dipahat berbentuk kembang terataı (lotus) dengan 12 kelopak daun bunga. Ternyata sebuah tiang batu di antaranya merupakan sebuah prasasti yang sangat aus. Tiang batu berukuran tinggi: $48 \mathrm{~cm}$, lebar bagian bawah: $24 \mathrm{~cm}$, lebar bagian atas: $20 \mathrm{~cm}$, dan tebal: $24 \mathrm{~cm}$. Tulisan dipahat di ke empat sisi tiang batu Sayang sekali ke tiga buah sisi prasasti batu itu tulisannya sangat rusak (90\%), sehingga tulisan yang kelihatan hanyalah huruf-huruf lepas yang tidak diketahui maknanya. Tetapi sebuah sisi di antaranya samar-samar masih dapat dibaca (sisi A)

Isi pokok prasasti tiang (pillar-inscription) itu antara lain sebagai berikut

1. Menyebut nama desa Wutit (wanua i wutit i ka

). Menarik perhatian bahwa toponim Wutit dapat diperkirakan Butit sekarang. Dukuh Butit terletak sekitar $250 \mathrm{~m}$. dari situs temuan (Dukuh Butit, Desa Tumbrek, Kec. Bandar, Kab. Batang). Nama desa lainnya hanya diketahui menggunakan awal nama Ka.

2. Baris ke enam menyebut perkataan manima (menetapkan sima). Jelas bahwa prasasti Wutit berkaitan dengan masalah pembebasan desa (sawah?) untuk keperluan tertentu. Pada baris ke sepuluh rupa-rupanya juga tertulis (s)inima (dijadikan sima)

3. Pada baris ke tujuh ganta(?)gna mani sang (h)yang wihā ... Mungkin di belakang wiha berbunyi ra (huruf terakhir sisi A). Apabila benar demikian berkaitan dengan bangunan agama Budha, sedangkan di situs Kandangan terdapat arca Nandi. Tetapi harus diingat bahwa arca Nandi dan ke empat tiang batu tersebut merupakan pindahan dari tempat lain.

4. Nama orang yang samar-samar masih terbaca yaitu si sita (sata) rama ni gana (si Sita (Sata) bapaknya Gana). Mungkin bertindak sebagai saksı pada upacara manima (manusuk sima)

Dari segi paleografi (terutama aksara ma) prasasti berasal dari sekitar abad $I X$ dan X Masehi. Jadi lebih muda apabila dibanding dengan batu Sojomerto (Melayu Kuno). Tetapi prasasti Wutit menggunakan huruf dan bahasa Jawa Kuno. Transkripsi sementara (sisi A) sebagai berikut

1. tidak terbaca (sangat aus),

2. tidak terbaca,

3. ... say yyaj

4. ... santa

5. (wa)nua i wutit i ka

6. ... si wata(?) ni manima mi (ji)

7. (ganta?) gna nu mani san (h)yan wihā (widā?)

8. tidak terbaca

9. ... si sa(si)ta rama ni gana

10. ... sa(ta?) (s)iima
11. tidak terbaca

12. tidak terbaca

Selain prasasti Wutit di daerah Semarang (barat), Batang, Kendal dan Pekalongan terdapat beberapa buah prasasti batu seperti: prasasti Bale Kambang, Sojomerto, Indrakila, dan Blado (kepokoh). Juga genta perunggu yang menyebut bhatāra i rbwan (cf. desa Reban dan alas roban)

\section{Prasasti Say Pamgat Swan.}

Prasasti San Pamgat Swan merupakan prasasti lingga semu (pseudo lingga) berukuran tinggi $70 \mathrm{~cm}$, dan garis tengah $23 \mathrm{~cm}$ Semula ditemukan di Desa Jetak II (Mungkid, Magelang). berdekatan dengan pabrik kertas Blabag. Saat ini parasasti tersebut disımpan di Museum Ronggowarsito, Semarang

Tulisan melingkar 3 baris di bagian atas (S1linder), menggunakan huruf dan bahasa Jawa Kuno. Perlu juga ditambahkan bahwa dalam prasasti gelar say hanya ditulis sa (kurang cecak)

Transkripsi batu Swan sebagai berikut

Swasti sakawarșätita 803 asujimasa ekadası suklapakșa werrukun kaliwuan tukrawāra dhanișta naksatra driamwata yoga tatkala sa (baca sap) pamgat swan manima.

Berart:

Selamat tahun Saka telah berjalan 803 (881 M) bulan Asuji, tanggal sebelas paro-terang. Wurukuך, Kaliwuan, hari Jumat, bintang (lunar mansion) Dhanișta, konjungsi Yoga, tatkala Saj Pamgat Swangmenetapkan sima

Sayang sekali prasasti tersebut tidak menyinggung nama desa yang ditetapkan oleh San Pamgat Swan menjadi sima. Tahun prasasti bertepatan dengan jaman pemerintahan Rake Kayuwangi (855-884 M.). Kayuwangi juga terkait dengan $C$. Pendem, Asu dan Lumbung yang terletak di lereng barat $G$. Merapi (pabrik kertas Blalak ke timur sekitar 15 km.). Ke tiga buah candi Hindu tersebut rupa-rupanya yang dimaksud dengan bhatāra i salingsıngan atau dharmmanira i salingsingan, karena di dekat candi Asu mengalir kali Tlingsing (bertemu dengan S. Pabelan. ${ }^{B}$

Sekian dan terimakasih

In Omnibus Caritas

Yogyakarta tgl. 19 Maret 1994

${ }^{E}$ Candi Pendem, Asu dan Lumbung ketigamya terletak d Kec. Dukuh (Kab Magetarig). Sampai sekarang terdapat 5 buah prasast yang terkait dengan kompleks percandian tersebur, yaitu: prasast Kurambitan I. Kurambitan II, Sri Manggala I. Sn Manggala II, dan tembaga Salingsingan. 



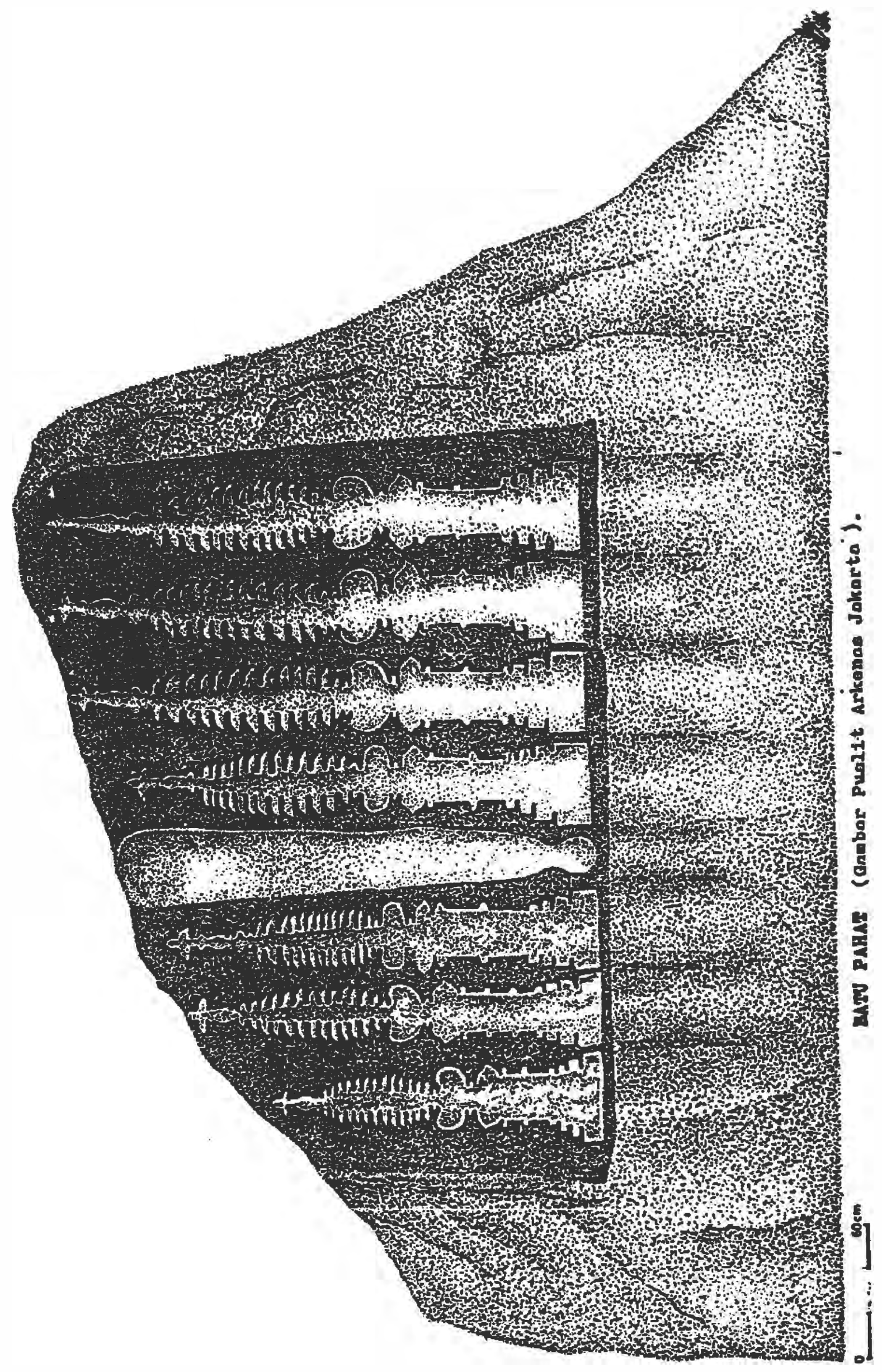


FAKSIXIL.

(Lebih-kxarang).

Prosnsti Baty Pahst.

Stūga IV.

Pattra (?). baris 10. dil

baris 11. (ด) 8 ก:

baris 1. क्रिध \& $\triangle$

batis 2. $\triangle \Delta \backsim \dot{T}$

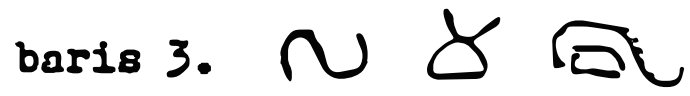

Prasasti Batr Sampat.

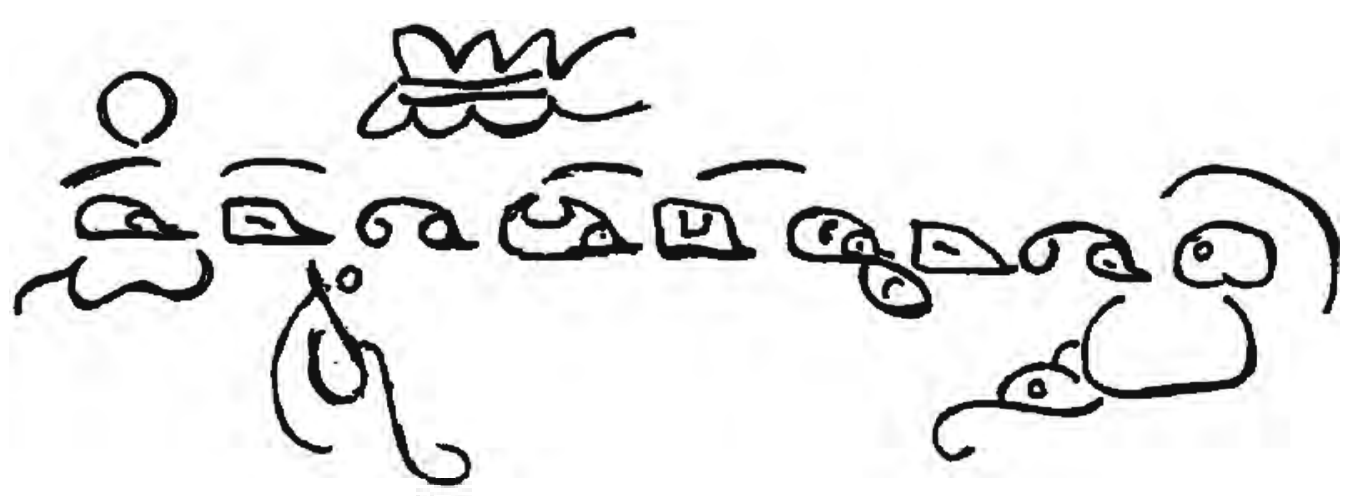


Prosost1 Tadu Tonth.

1. $39.09 \cos ^{\circ}$

2. संखियं०क)

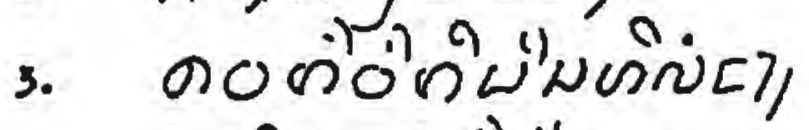

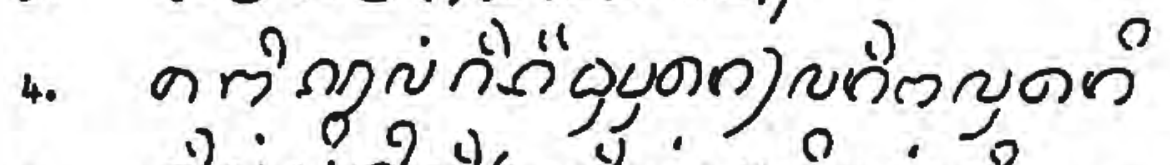

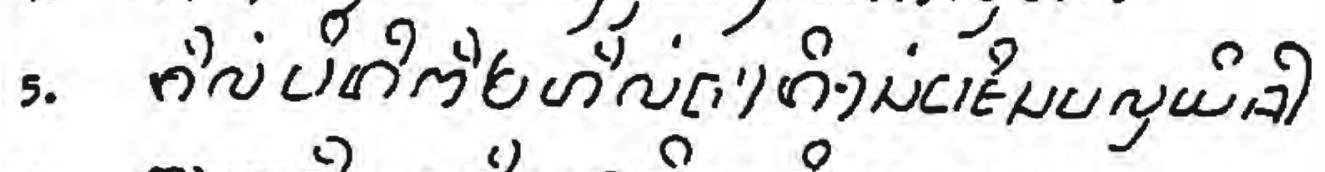

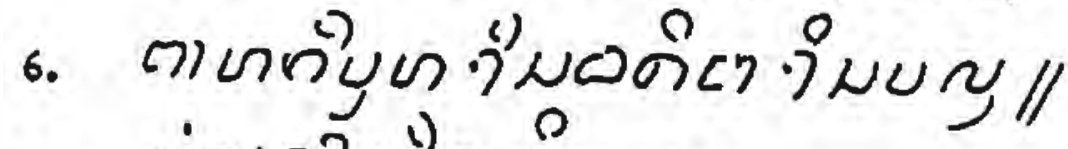

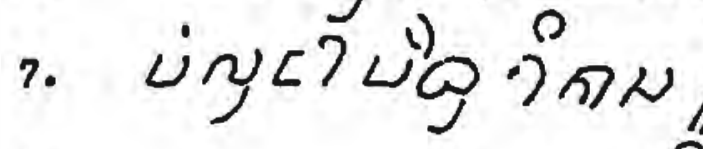

8.

9.

10.

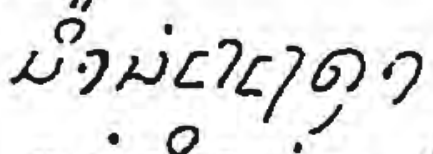

$$
\begin{aligned}
& \text { ग0 } 0^{\circ} \text { 년 }
\end{aligned}
$$

NUY.

Prosost1 Wut1t.

1.

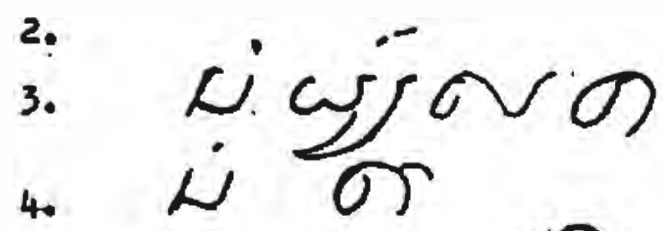

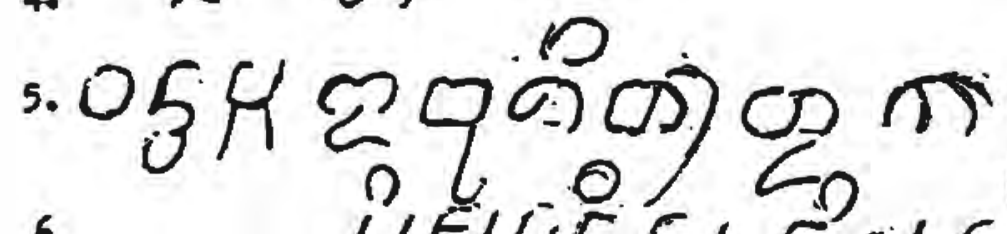

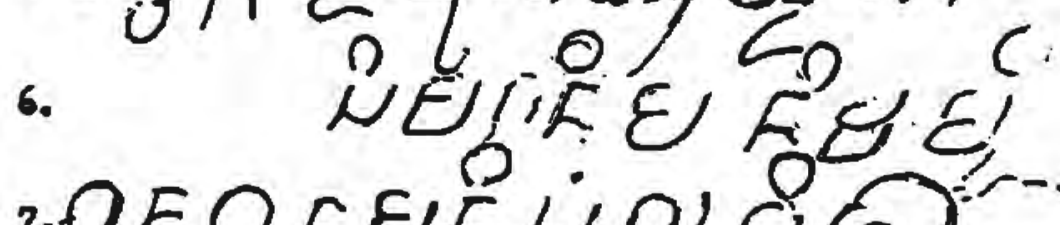

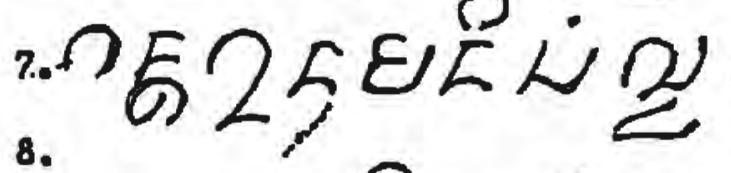

. LUSIER

- va D DES

10. NORIEE 
Prosasti say Paugat STay.

1) 대슷

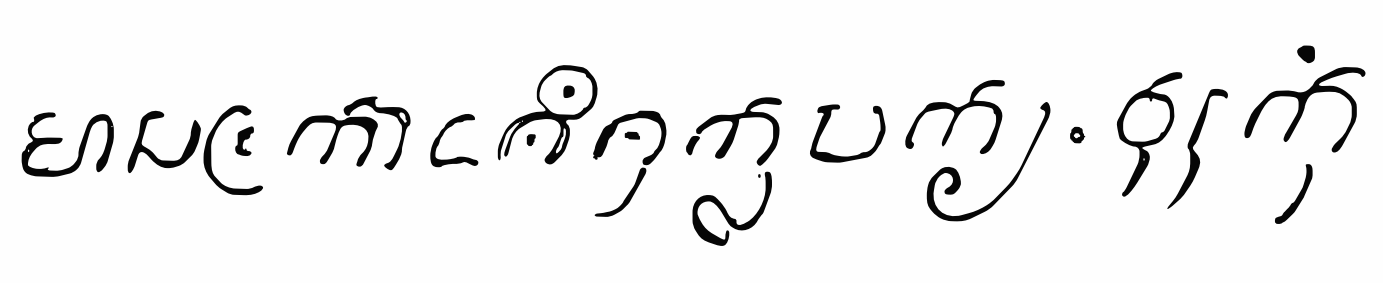

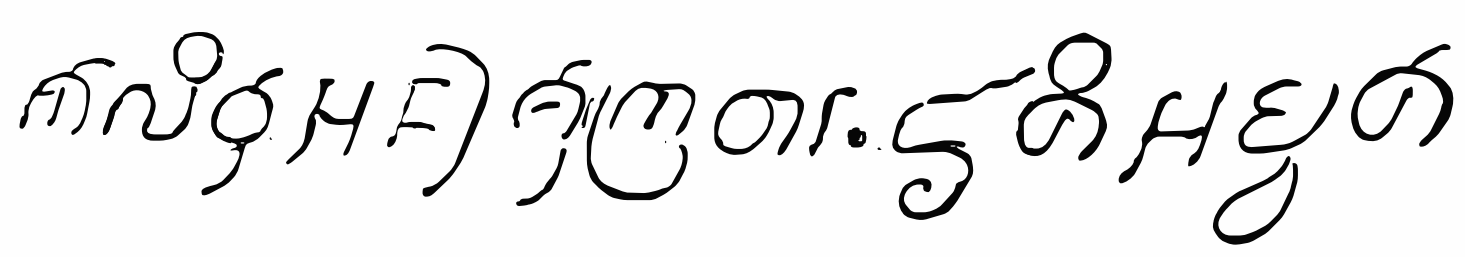

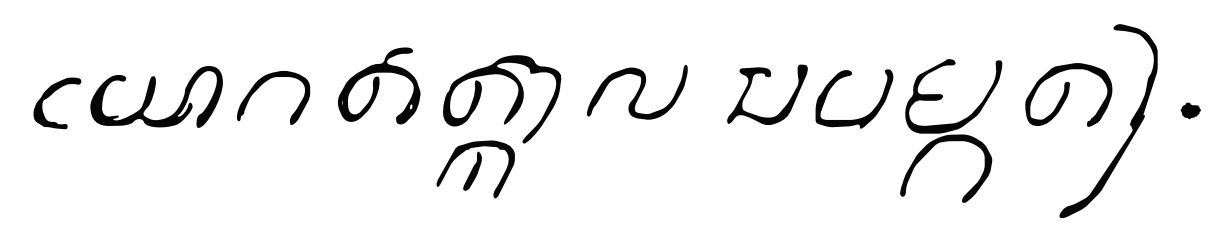

¿ुछRिध 